\title{
Effect of phosphorus, sulphur and different irrigation levels on phenological traits of Triticale
}

\author{
Babar Iqbal ${ }^{1 *}$, Bashir Ahmad ${ }^{1}$, Inam Ullah ${ }^{1}, \operatorname{Imran}^{1}$, Asad Ali Khan ${ }^{1}$, \\ Shazma Anwar ${ }^{1}$, Asad Ali ${ }^{2}$, Khurrum Shahzad ${ }^{1}$ and Shehryar Khan ${ }^{1}$ \\ 1. Department of Agronomy, The University of Agriculture,Peshawar, Pakistan \\ 2. Department of Agriculture, Abdul Wali Khan University, Mardan, Pakistan \\ *Corresponding author's email: agronomist19388@yahoo.com \\ Citation \\ Babar Iqbal, Bashir Ahmad, Inam Ullah, Imran, Asad Ali Khan, Shazma Anwar, Asad Ali, Khurrum Shahzadand \\ Shehryar Khan. Effect of phosphorus, sulphur and different irrigation levels on phenological traits of Triticale. Pure \\ and Applied Biology. Vol. 5, Issue 2, 2016, pp303-310. http://dx.doi.org/10.19045/bspab.2016.50039
}

Received: 23/09/2015

Revised: 22/02/2016

Accepted: 29/02/2016

Online First: 21/03/2016

\section{Abstract}

This field experiment was conducted at Agronomy Research Farm, The University of Agriculture Peshawar during rabi season 2013-2014 to study the response of triticale to phosphorus (P), sulphur (S) and different irrigation (I) levels. The experiment was comparised on randomized complete block (RCB) design with split plot arrangement having three replications. A sub plot size of $5.4 \mathrm{~m}^{2}$ having six rows of $3 \mathrm{~m}$ in length was used. Irrigation numbers (I1 (seedling), $\mathrm{I}_{2}$ (seedling + tillering), $\mathrm{I}_{3}$ (seedling + tillering + booting)) were applied to the main plot while phosphorus $\left(60,90\right.$ and $\left.120 \mathrm{~kg} \mathrm{ha}^{-1}\right)$ and sulphur (10, 20 and $\left.30 \mathrm{~kg} \mathrm{ha}^{-1}\right)$ were applied in combination at sub plot while one control having no $\mathrm{P}$ and $\mathrm{S}$ application. All of the phosphorus and sulphur were applied at sowing time. The result of this study revealed that more days to anthesis (125) were produced by irrigation applied two times $\left(\mathrm{I}_{2}=\right.$ seedling + tillering), more days to physiological maturity (167), and harvest index (32\%) were recorded by irrigation applied one time $\left(\mathrm{I}_{1}=\right.$ seedling) while higher plant height $(114 \mathrm{~cm})$ and leaf area $\left(21 \mathrm{~cm}^{2}\right)$ were recorded by irrigation applied three times $\left(\mathrm{I}_{3}=\right.$ seedling + tillering + booting $)$. Plots that are treated with phosphorus@ @ $90 \mathrm{~kg} \mathrm{ha}^{-1}$ produced more days to anthesis (126), plant height (114 $\mathrm{cm}$ ) and leaf area $\mathrm{cm}^{2}$ (21) while more days to physiological maturity (167) was formed by $60 \mathrm{~kg}$ $\mathrm{P} \mathrm{ha}^{-1}$. Sulphur applied to the plots @ $20 \mathrm{~kg} \mathrm{ha}^{-1}$ produced higher days to anthesis (126). It can be concluded from this study that better physiological traits were produced from irrigation applied two times $\left(\mathrm{I}_{2}=\right.$ seedling + tillering) in grouping with $90 \mathrm{~kg} \mathrm{P} \mathrm{ha}^{-1}$ and $20 \mathrm{~kg} \mathrm{~S} \mathrm{ha}^{-1}$.

Key words: Triticale (Triticosecale wittmack); Phosphorus; Sulphur; Irrigation number;

\section{Phenological traits}

\section{Introduction}

Triticale, botanically known as Triticosecale wittmack belongs to family poaceae and tribe Hordeae. It is relatively a new cereal crop which is a product of crosses between the genera Tritico of which wheat is member and secale of which rye is the member, gaining half of its name from each genus. Triticale is the "man-made" cereal crop. Triticale has been evolved by breeders 
where kernal are comparatively large and they contain higher content of Lysin (18\% of $\mathrm{N}$ ) and protein (14.7\%) than wheat, maize, millet and sorghum [1]. Triticale is a crop of great importance for making not only bread but also other food products, such as pastas, breakfast cereals, etc. [2]. In Pakistan when semi dwarf, high yielding wheat was introduced, the national average yield was nearly doubled (1563 kg ha-1) though it is still lower than the major wheat growing countries of the world like France and Mexico. In world Poland produce triticale on large area of 1,258,700 ha while Mexico grow it on 723 ha area having lowest area for the cultivation of triticale in the world [3].

Irrigation is needed in many areas of the country for good crop growth and proper grain development as rainfall is inadequate and erotic throughout the country. Water, the most essential but costly input, plays a key role in growth and productivity of all plants, if applied judiciously. Some crops need more water than others but every crop has its own water requirement. So it is important to irrigate the crops as per their needs because too much or too little water can limit the plant growth.

The advantages of Triticale were particularly observable in the Mediterranean environment where yield and biomass were recorded almost twice as compared to wheat, associated with similar magnitude differences in Radiation use efficiency [4].

Pakistan is very low in yield of various cereals as compared to other developed countries. Many factors are responsible for the decline in yield. One of the important factor limiting yield is plant nutrition. Triticale varieties were more response to phosphorus application with the grain yield in some genotypes were three times higher in $80 \mathrm{~kg}$ phosphorus treatments [5]. As $\mathrm{P}$ is an expensive nutrient compared to $\mathrm{N}$, and wheat while grown on alkaline calcareous soils commonly suffers from $\mathrm{P}$ deficiency. It is, therefore, very important to manage it properly to achieve higher benefits [6]. $\mathrm{P}$ reduces lodging by strengthening the straw in cereals and also enhances the resistance of crop to various diseases. It plays a vital role in growth of a plant, division of cell and formation of nucleus. $\mathrm{P}$ is also accountable for the development of RNA and DNA which transmit heredity materials.

Sulphur (S) is a necessary plant nutrient as it plays a key role in plant metabolism. The deficiency of $\mathrm{S}$ has been extensive in agricultural soil of most European countries in the past few years. The major reasons for $S$ deficiency are reductions in $\mathrm{SO}_{2}$ emission, use of fertilizers containing less sulphur content, the less return of sulphur with FY manure and less use of fungicides that contain sulphur content $[7,8,9]$.

Although there is less literature available on combined uses of irrigation, phosphorus and sulphur for triticale production, this study was designed to verify the effect of irrigation, phosphorus and sulphur on the phenological traits of triticale in Khyber Pakhtunkhwa.

\section{Materials and methods}

An experiment entitled "Effect of phosphorus, sulphur and different irrigation levels on phenological traits of triticale" was conducted at Agronomy Research Farm, The University of Agriculture, Peshawar, Pakistan during rabi season 2013-14. The experiment was laid out in Randomized Complete Block Design with split plot arrangement having three replications. The size of subplot was $3 \times 1.8 \mathrm{~m}^{2}$. Row to row distance was $30 \mathrm{~cm}$ having six rows. Irrigation numbers were allotted to main plot (Factor A) while phosphorus and sulphur were applied in combination to subplots (Factor B). Phosphorus in the form of SSP in various levels $\left(60,90,120 \mathrm{~kg} \mathrm{ha}^{-1}\right)$ was applied which contains $18 \% \mathrm{P}_{2} \mathrm{O}_{5}$ and $12 \%$ 
sulphur. Sulphur was applied in the form of ammonium sulphate in various levels (10, 20, $30 \mathrm{~kg} \mathrm{ha}^{-1}$ ) at the time of sowing. Sulphur applied from ammonium sulphate was subtracted from the SSP source. $\mathrm{pH}$ of the soil was 7.6 - 7.7. Nitrogen was applied at its recommended rate of $120 \mathrm{~kg} \mathrm{ha}^{-1}$ in the form of urea. All other agronomic practices were remained uniform for all the treatments. Data concerning days taken by triticale from sowing till emergence were taken by counting down the days from sowing till $50 \%$ plants emerge in each plot. By counting the total days from date of sowing till the date when $75 \%$ anthesis occurred, days to anthesis was calculated. Days to physiological maturity was recorded by counting the days from date of sowing to the date when $75 \%$ plants become physiologically mature. Entire loss of the green color from the glumes and maximum dry weight accumulation (when no more photosynthates were going to the grain) considered as indication of physiological maturity. By measuring leaf length, width and known correction factor multiplication, the mean leaf area was calculated. Harvest index can be calculated simply by economical yield divided by biological yield and multiplied with 100 . Data was statistically analyzed according to the procedure described by Steel et al. (1996) [10] for randomized complete block design and means were separated by least significant differences test $(\mathrm{P}<0.05)$ upon significant $F$ test. Fig. 1. Presented the data concerning mean monthly rainfall, temperature and humidity recorded during the crop growth period.

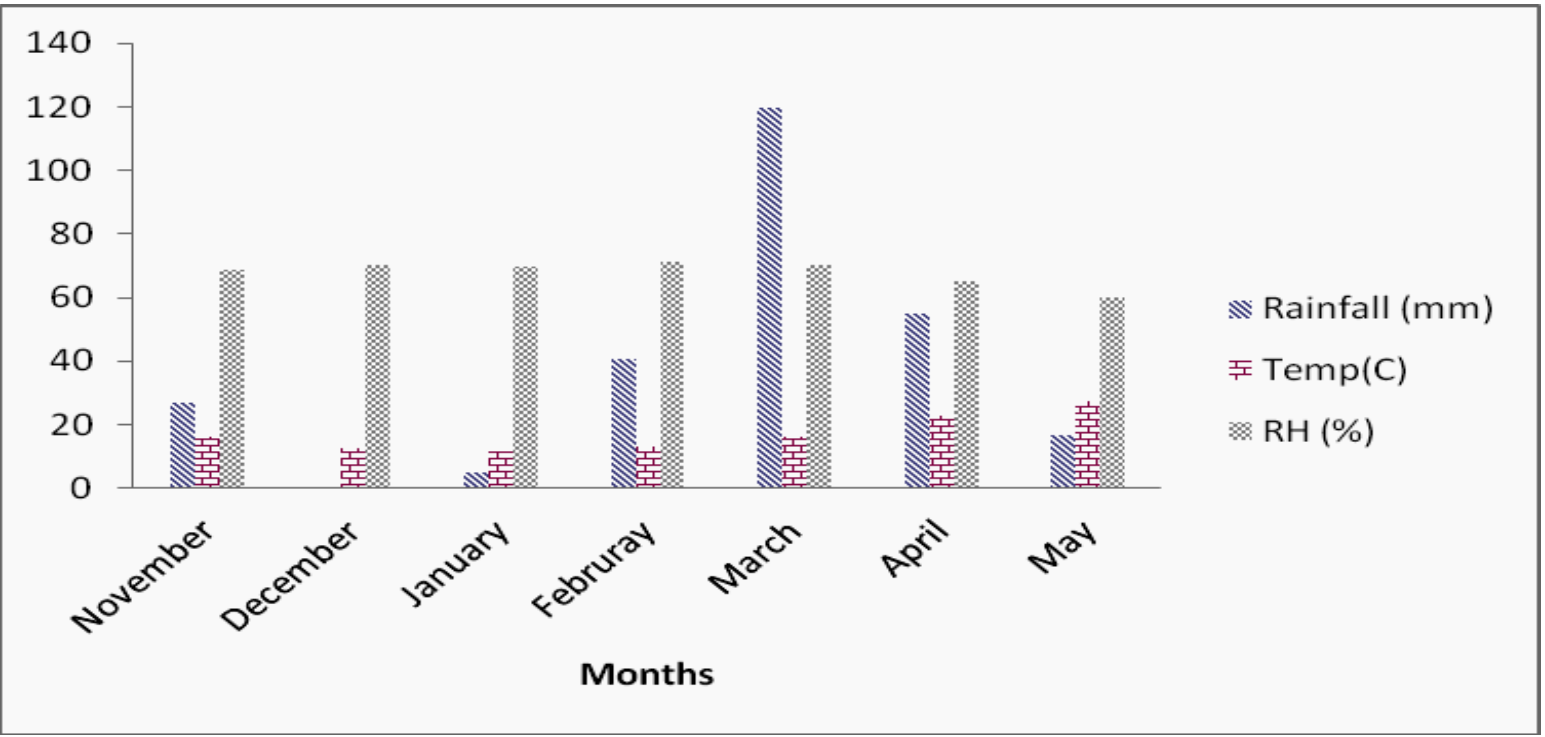

Figure 1. Annual rainfall $(\mathrm{mm})$, temperature $\left(\mathrm{C}^{0}\right)$ and relative humidity $(\%)$ during rabi 2013-2014

\section{Results and discussion Days to emergence}

Data regarding days to emergence are presenting in Table 1 . The data revealed that irrigation number, phosphorus and sulphur levels and their interactions had nonsignificant effect on days to emergence.
Data concerning days to emergence of triticale showed that phosphorus, sulphur and irrigation numbers had non-significant affect. This might be due to the seed which used stored food during germination and did not be depended on external minerals (nutrients/ fertilizers) for germination. There 
are more other reasons for showing no significant impact that there no effect of fertilizers in the early growth stages where plants ready to emerge. These results are in procession with [11] who stated that there is no effect of fertilizer on emergence.

\section{Days to anthesis}

Perusal of the data revealed significant impact of irrigation numbers, phosphorus, sulphur levels and control vs. rest comparison on days to anthesis. Interactions between I x control vs. rest and I x P showed significant influence on days to anthesis (Table 1). Mean comparison of the data showed that two irrigations $\left(\mathrm{I}_{2}=\right.$ seedling + tillering stage) took higher (125) days to anthesis which was same with irrigation applied three times $\left(\mathrm{I}_{3}=\right.$ seedling + tillering + booting stage) and statistically different from one time irrigation applied (seedling $\left(\mathrm{I}_{1}\right)$ stage). Control plots took less (121) days to anthesis. Phosphorus levels showed significant effect on days to anthesis. Phosphorus level of $90 \mathrm{~kg} \mathrm{ha}^{-1}$ resulted in higher (126) days to anthesis. Different sulphur levels also showed positive response in term of days to anthesis. Sulphur used at the rate of $20 \mathrm{~kg} \mathrm{ha}^{-1}$ took higher (126) days to anthesis whereas control plots took (121) days to anthesis. In case of interaction between irrigation and phosphorus, days to anthesis appreciably increased at all irrigations levels with rising phosphorus up to $90 \mathrm{~kg} \mathrm{ha}^{-1}$. Irrigation, phosphorus, sulphur, control vs. rest comparison, I x control vs. rest and I x P interactions considerably $(\mathrm{P} \leq 0.05)$ influenced days to anthesis. Irrigation at seedling stage took less days to anthesis as compared to other levels of irrigation which took higher days to anthesis. This might be due to more growth and longer time to produce flower. These results are different from the findings of Ngwako and Mashiqa (2013) [12] who stated that days taken to anthesis were not significantly influenced by irrigation numbers. With increasing $\mathrm{P}$ levels days to anthesis were decreased. Phosphorus applied at $90 \mathrm{~kg} \mathrm{ha}^{-1}$ took higher days to anthesis while untreated plots took less (121) days to anthesis. These results are in line with [13] who reported that optimum amount of phosphorus reduced days taken to anthesis. Sulphur application at $20 \mathrm{~kg} \mathrm{ha}^{-1}$ took higher days to anthesis. This might be due to the fertilizer application with delayed days to anthesis. These results are different from the results of [14] who reported that there was effect of fertilizer on days to anthesis.

\section{Days to physiological maturity}

Statistically analyzed data showed significant impact of irrigation numbers, phosphorus and control vs. rest comparison on days to physiological maturity. Every interaction was non-significant except I x control vs. rest and I x P. Mean comparison of the data showed that irrigation applied one time at $\left(\mathrm{I}_{1}=\right.$ seedling stage $)$ took higher (167) days to physiological maturity. Phosphorus levels indicated considerable result on days to physiological maturity. Phosphorus level of $60 \mathrm{~kg} \mathrm{ha}^{-1}$ resulted in higher (167) days to physiological maturity which is statistically at par with phosphorus level at the rate of $90 \mathrm{~kg} \mathrm{ha}^{-1}$ and with phosphorus level $120 \mathrm{~kg} \mathrm{ha}^{-1}$. Higher (171) days to physiological maturity was counted in control plots as compared to the rest of other plots which took minimum (166) days to physiological maturity. Regarding interactive effect of irrigation and phosphorus, days to physiological maturity, significantly increased at all irrigation numbers with escalating $\mathrm{P}$ up to $60 \mathrm{~kg} \mathrm{ha}^{-1}$. Irrigation, phosphorus, control vs. rest comparison, $\mathrm{I} x$ control vs. rest and I x $\mathrm{P}$ interactions considerably $(\mathrm{P} \leq 0.05)$ inclined days to physiological maturity. Irrigation at seedling stage took higher days to physiological maturity. These results are same with the finding of Ngwako and 
Mashiqa (2009) [12] who stated that days taken to maturity were significantly influenced by irrigation stages. With increasing $\mathrm{P}$ levels days to maturity were decreased. Phosphorus applied at $60 \mathrm{~kg} \mathrm{ha}^{-1}$ took higher days to maturity. These results are in line with [13] who reported that optimum amount of phosphorus minimize days to maturity.

\section{Plant height}

Statistically analyzed the data revealed significant impact of irrigation numbers, phosphorus and control vs. rest comparison on plant height. All interactions showed non-significant effect except I x control vs. rest and I x S. Mean comparison of the data showed that three irrigations numbers $\left(\mathrm{I}_{3}=\right.$ seedling + tillering + booting stage) produced taller plants $(114 \mathrm{~cm})$. Phosphorus levels showed significant impact on plant height. Phosphorus applied at the rate of 90 $\mathrm{kg} \mathrm{ha}{ }^{-1}$ resulted taller plants $(114 \mathrm{~cm})$ whereas control plots resulted lower plant height $(96 \mathrm{~cm})$. Interaction between irrigation and sulphur, plant height significantly increased with increasing irrigation up to third irrigation $\left(\mathrm{I}_{3}=\right.$ seedling + tillering + booting stage) at all sulphur levels. Irrigation, phosphorus and control vs. rest comparison, I x control vs. rest and I x S interactions considerably $(\mathrm{P} \leq 0.05)$ influenced plant height. Irrigation at seedling + tillering+ booting stage produced taller plants. This might be due to sufficient availability of nutrients having no moisture stress. These results are also same with [15] who reported that irrigation treatments significantly affected plant height. Increasing $\mathrm{P}$ levels considerably increased plant height. Phosphorus applied at the rate of $90 \mathrm{~kg} \mathrm{ha}{ }^{-1}$ produced optimum plant height. These results showed conformity with the findings of [16] who reported that rising $\mathrm{P}$ rate up to a certain limit increase plant height.

\section{Leaf area}

Data concerning leaf area $\mathrm{cm}^{2}$ as exaggerated by phosphorus, sulphur and different irrigation levels (Table 1). Statistically analyzed data showed significant impact of irrigation number, phosphorus and control vs. rest comparison on leaf area $\mathrm{cm}^{2}$ while sulphur levels showed non-significant effect on leaf area $\mathrm{cm}^{2}$. All interactions were also significant impact on leaf area $\mathrm{cm}^{2}$. Three irrigations $\left(\mathrm{I}_{3}\right.$ $=$ seedling + tillering + booting stage $)$ produced higher $\left(21 \mathrm{~cm}^{2}\right)$ leaf area $\mathrm{cm}^{2}$ which was higher than control plots (17 $\mathrm{cm}^{2}$ ). Phosphorus levels showed significant effect on leaf area $\mathrm{cm}^{2}$. Level of $90 \mathrm{~kg} \mathrm{P} \mathrm{ha}^{-1}$ produced privileged $\left(21 \mathrm{~cm}^{2}\right)$ leaf area while control resulted in minimum $\left(17 \mathrm{~cm}^{2}\right)$ leaf area. In case of interactions between phosphorus and sulphur, leaf area $\mathrm{cm}^{2}$ significantly increased with increasing $\mathrm{P}$ rates up to $60 \mathrm{~kg} \mathrm{ha}^{-1}$ and sulphur rates up to $30 \mathrm{~kg} \mathrm{ha}^{-1}$ and then decrease respectively at $90 \mathrm{~kg} \mathrm{ha}^{-1}$ and $120 \mathrm{~kg} \mathrm{ha}^{-1}$. Interaction between irrigation and phosphorus resulted that improved leaf area at all irrigations levels by rising $\mathrm{P}$ rates up to $120 \mathrm{~kg} \mathrm{ha}^{-1}$. The interaction between irrigation and sulphur revealed that leaf area $\mathrm{cm}^{2}$ drastically improved with increasing irrigation levels up to three irrigations (seedling + tillering+ booting stage) at $20 \mathrm{~kg}$ $\mathrm{S} \mathrm{ha}^{-1}$ and then decreased at $30 \mathrm{~kg} \mathrm{~S} \mathrm{ha}^{-1}$. Irrigation, phosphorus and control vs. rest comparison, P x S, I x control vs. rest, I x P, I x S and I x P x S interactions considerably $(\mathrm{P} \leq 0.05)$ influenced leaf area $\left(\mathrm{cm}^{2}\right)$. Irrigation at $\left(\mathrm{I}_{3}=\right.$ seedling + tillering + booting stage) recorded higher leaf area $\mathrm{cm}^{2}$. These results are same to [17] who stated that higher irrigation produced higher leaf area $\mathrm{cm}^{2}$. Phosphorus application considerably affected leaf area $\mathrm{m}^{2}$. Phosphorus applied at $90 \mathrm{~kg} \mathrm{ha}^{-1}$ produced optimum leaf area $\left(\mathrm{cm}^{2}\right)$ and minimum leaf area $\left(\mathrm{cm}^{2}\right)$ was produced by control plots. 
These consequences are in concurrence with [16] who reported that $\mathrm{P}$ deficit decrease leaf area which in turn gives us smaller leaves.

\section{Harvest index (\%)}

Analysis of the data confirmed that irrigation levels and control vs. rest noticeably affected harvest index. All interactions showed significant effect on harvest index. Irrigation applied one time (seedling stage) maintained greater harvest index $(32 \%)$ while control plots showed minimum (29\%) harvest index. Interaction between phosphorus and sulphur the harvest index improved up to $90 \mathrm{~kg} \mathrm{P} \mathrm{ha}^{-1}$ and $30 \mathrm{~kg}$ $\mathrm{S} \mathrm{ha}^{-1}$ and then tends to decreased at $120 \mathrm{~kg}$ $\mathrm{P} \mathrm{ha}^{-1}$. The interaction between irrigation and phosphorus, the harvest index increased at seedling stage at all phosphorus levels and then decreases as irrigation level increases. The interaction between irrigation and sulphur the harvest index decreased at $30 \mathrm{~kg}$ sulphur $\mathrm{ha}^{-1}$ at all irrigation levels. Irrigation, control vs. rest, I x control vs. rest, $\mathrm{P} \times \mathrm{S}$ and $\mathrm{I} \times \mathrm{P}, \mathrm{I} \times \mathrm{S}$ and $\mathrm{I} \times \mathrm{P} \times \mathrm{S}$ interactions considerably $(\mathrm{P} \leq 0.05)$ affected harvest index. Irrigation at seedling stage produced higher harvest index $\%$ as compared with control plots which gave the lowest harvest index. These results are diverse from the results of [18] who stated that more irrigation applied produced higher harvest index.

Table 1. Days to emergence (DTE), anthesis (DTA), physiological maturity (PM), plant height $(\mathrm{cm})$, leaf area $\left(\mathrm{cm}^{2}\right)$ and harvest index (\%) of triticale as affected by phosphorus, sulphur and different irrigation levels.

\begin{tabular}{lcccccc}
\hline Treatment & DTE & DTA & DTPM & Plant height & Leaf area & Harvest Index\% \\
\hline Irrigation nos & & & & & & \\
\hline $\mathrm{I}_{1}$ & 11 & $123 \mathrm{~b}$ & $167 \mathrm{a}$ & $111 \mathrm{~b}$ & $19 \mathrm{c}$ & 32 \\
\hline $\mathrm{I}_{2}$ & 11 & $125 \mathrm{a}$ & $166 \mathrm{~b}$ & $113 \mathrm{a}$ & $20 \mathrm{~b}$ & 31 \\
\hline $\mathrm{I}_{3}$ & 11 & $125 \mathrm{a}$ & $165 \mathrm{c}$ & $114 \mathrm{a}$ & $21 \mathrm{a}$ & 29 \\
\hline LSD $(0.05)$ & $\mathrm{ns}$ & 1 & 1 & 2 & 0.5 & 1 \\
\hline Phosphorus $\left(\mathbf{k g ~ h a}^{-1}\right)$ & & & & & & \\
\hline 60 & 12 & $125 \mathrm{~b}$ & $167 \mathrm{a}$ & $113 \mathrm{ab}$ & $20 \mathrm{~b}$ & 31 \\
\hline 90 & 11 & $126 \mathrm{a}$ & $167 \mathrm{a}$ & $114 \mathrm{a}$ & $21 \mathrm{a}$ & 31 \\
\hline 120 & 11 & $124 \mathrm{c}$ & $164 \mathrm{~b}$ & $111 \mathrm{~b}$ & $20 \mathrm{~b}$ & 31 \\
\hline LSD $(0.05)$ & $\mathrm{ns}$ & 0.95 & 0.78 & 3 & 0.7 & $\mathrm{~ns}$ \\
\hline Sulphur $\left(\mathbf{k g ~ h a} \mathbf{~ h}^{-1}\right)$ & & & & & & \\
\hline 10 & 11 & $124 \mathrm{~b}$ & 165 & 113 & 20 & 31 \\
\hline 20 & 11 & $126 \mathrm{a}$ & 166 & 112 & 20 & 30 \\
\hline 30 & 12 & $124 \mathrm{a}$ & 166 & 112 & 20 & 31 \\
\hline LSD $(0.05)$ & $\mathrm{ns}$ & 0.95 & $\mathrm{~ns}$ & $\mathrm{~ns}$ & $\mathrm{~ns}$ & $\mathrm{~ns}$ \\
\hline Control & $\mathbf{1 2}$ & $\mathbf{1 2 1}$ & $\mathbf{1 7 1}$ & $\mathbf{9 6}$ & $\mathbf{1 7}$ & $\mathbf{2 9}$ \\
\hline Interaction & & & & & & \\
\hline P x S & $\mathrm{ns}$ & $\mathrm{ns}$ & $\mathrm{ns}$ & $\mathrm{ns}$ & $*$ & $*$ \\
\hline Ix P & $\mathrm{ns}$ & $*$ & $*$ & $\mathrm{~ns}$ & $*$ & $*$ \\
\hline Ix S & $\mathrm{ns}$ & $\mathrm{ns}$ & $\mathrm{ns}$ & $*$ & $*$ & $*$ \\
\hline Ix P x S & $\mathrm{ns}$ & $\mathrm{ns}$ & $\mathrm{ns}$ & $\mathrm{ns}$ & $*$ & $*$ \\
\hline & & & & & & \\
\hline
\end{tabular}




\section{Conclusion and recommendation}

It was concluded that irrigation applied three times delayed anthesis, physiological maturity, plant height and leaf area. $\mathrm{P}$ applied at the rate of $90 \mathrm{~kg} \mathrm{ha}^{-1}$ delayed anthesis, maturity, plant height and leaf area. Sulphur applied at the rate of $20 \mathrm{~kg} \mathrm{ha}^{-1}$ dealyed anthesis in triticale. Therefore, it is recommended that irrigations applied two times in combination with phosphorus $90 \mathrm{~kg}$ $\mathrm{ha}^{-1}$ and Sulphur $20 \mathrm{~kg} \mathrm{ha}{ }^{-1}$ for better phonological traits of triticale.

\section{Authors' contributions}

Conceived and designed the experiments: B Iqbal, B Ahmad \& Inamullah, Performed the experiments: B Iqbal, Imran, K Shahzad \& S KhanAnalyzed the data: B Iqbal, Inamullah \& AA Khan, Contributed reagents/ materials/ analysis tools: AA Khan, S Anwar \& A Ali, Wrote the paper: B Iqbal.

\section{References}

1. Khan MA \& Rashid J (1987). Nutritional quality and technological value of triticale. Asian Food J 3(1): 17-20.

2. Raja JM (2003). Comparative performance of three cereals with different phosphorus rates under rainfed conditions. MSc (Hons) thesis. NWFP Agri. Univ. Peshawar.

3. FAO (2012). Food and Agriculture Organization statistical databaseagriculture.

4. Campuzano GE, Miralles DJ \& Slafer GA (2005). Differences in yield, biomass and their components between triticale and wheat grown under contrasting water and nitrogen environments. Field Crops Res 128: 167-179.

5. Monasterio, JIO, Pena RJ, Pfeiffer WH \& Hede AH (2001). Phosphorus use efficiency, grain yield, and quality of triticale and durum wheat under irrigated conditions. Proceedings of the 5th International Triticale Symposium, Annex June 30 - July 5, Radzików, Poland
6. Malik DM, Chaudhry RA \& Sherazi SJA (1992). Management of phosphorus for wheat production in Punjab. In: Proc. Symp. On the role of phosphorus in crop production. NFDC, Islamabad. Pakistan. 175-195.

7. Schnug E (1991). Sulphur nutritional status of European crops and consequences for agriculture. Sulphur Agric 15: 7-12.

8. Ruiter D, Martin JM \& RJ (2001). Management of nitrogen and sulphur fertiliser for improved bread wheat (Triticum aestivum L.) quality. NZ J Crop Hort 29: 287-299.

9. Scherer HW (2001). Sulphur in crop production - invited paper. Eur J Agron 14: 81-111.

10. Steel RGD \& Torrie JH (1980). Principles and procedure of statistics. A biological approach $2^{\text {nd }}$ ed. McGraw Hill Inc. New York.

11. Walter EB, Christianson CB \& Lamothe AG (1995). The effect of nitrogen fertilizer on growth, grain yield and yield component of malting barley. Field Crops \& Res 43: 87-99.

12. Ngwako $S \&$ Mashiqa PK (2013). The effect of irrigation on the growth and yield of winter wheat (Triticum aestivum L.) cultivars. Intl J Agri Crop Sci 5(9): 976-982.

13. Khalil SK, Khan S, Rahman A, Khan AZ, Khalil IH, Amanullah, Wahab S, Mohammad F, Nigar S, Zubair M, Parveen S \& Khan A (2010). Seed priming and phosphorus application enhance phenology and dry matter production of wheat. Pak J Bot 42(3): 1849-1856.

14. Saeed B, Gul H, Khan AZ \& Parveen L (2012). Growth factors and straw yield of wheat cultivars in relation with nitrogen and sulfur fertilization. J Agri \& Bio Sci 7(1): 13-22. 
15. Sarwar N, Maqsood M, Mubeen K, Shehzad M, Bhullar MS, Qamar R \& Akbar N (2010). Effect of different levels of irrigation on yield and yield components of wheat cultivars. Pak J Agri Sci 47(3): 371-374.

16. Rahim A, Ranjah AM, Rahmatullah \& Waraich EA (2010). Effect of phosphorus application and irrigation scheduling on wheat yield and phosphorus use efficiency. Soil Sci Soc Pak 29(1): 15-22.
17. Mubeen M, Ahmad A, Wajid A, Khaliq T, Sultana SR, Hussain S, Ali A, Ali H, Nasim W (2013). Effect of growth stage-based irrigation schedules on biomass accumulation and resource use efficiency of wheat cultivars. American J Plant Sci 4:1435-1442.

18. Maqsood M, Ali A, Aslam Z, Saeed M \& Ahmad S (2002). Effect of irrigation and nitrogen levels on grain yield and quality of wheat (Triticum aestivum L.) Int J Agri Biol 4(1): 164-165. 